\title{
180 years of botanical investigations in Antarctica and the role of Brazil
}

\section{Paulo E.A.S. Câmara ${ }^{1,2 *}$ and Micheline Carvalho-Silva ${ }^{1,2}$ (i)}

Received: March 19, 2020

Accepted: May 31, 2020

\begin{abstract}
Botany is one of the oldest sciences done above the $60^{\circ} \mathrm{S}$ parallel with more than 180 years passing since the first professional botanist collected plants in Antarctica. Far from being a barren place, plants constitute an important part of polar ecosystems. Brazil is one of only 29 countries in the world with consultative status and to currently develop botanical studies in Antarctica. We discuss the importance of polar science to Brazil and the role that Brazil has in the international austral-polar scientific community, as well as the importance of its newly inaugurated scientific station.
\end{abstract}

Keywords: Antarctic Treaty, botany, Brazil, J.D. Hooker, PROANTAR

\section{Introduction}

Antarctica includes all land and ocean above the latitude of $60 \mathrm{o}$ S. With an area of around 14 million $\mathrm{km}^{2}$, the continent comprises about $8 \%$ of the Earth's surface, although only about $0.2 \%$ of this area is currently free of permanent ice. Within this area, the equivalent of about three Amazon basins would fit, and holding in its ice is about $70 \%$ of world's freshwater, Antarctica is largely unknown by most Brazilians, including the scientific community. The region has a relatively short human history, the Antarctic Peninsula only being discovered in the early $19^{\text {th }}$ Century and the main body of the continent at the very end of the same century. Human presence on the continent is therefore quite recent and Antarctica is the only continent without any permanent human settlements. In the early $20^{\text {th }}$ Century most human activity was associated with the 'Heroic Age' of continental exploration. The bulk of scientific activity initiated after World War II, and particularly after the International Geophysical Year (IGY) of 1957/58.

Antarctica today is not part of any national territory, and instead it is currently governed by the Antarctic Treaty, an international treaty that was negotiated in 1959 following the momentum created by the IGY and came into force in 1961. Under the Antarctic Treaty, Antarctica is defined as a continent exclusively dedicated to peaceful and, particularly scientific purposes. Among other things, weapons, nuclear facilities, military bases and activities, as well as garbage disposal are banned. While the Treaty remains in force, previous territorial claims are placed in abeyance and all Parties to the Treaty (signatory nations) are free to undertake their scientific programs anywhere in the region. The Treaty was originally negotiated and agreed by 12 nations. Other countries have since joined, and currently there are 59 signatory nations. Out of these, 29 are consultative parties, which gives them decision-making power through having the right to vote in the annual Antarctic Treaty Consultative Meetings (ATCM) where all matters relating to Antarctica are discussed. Decisions within the ATCM are made by consensus amongst the consultative parties. The Treaty itself does not have any enforcement authority, and to become effective, its agreed decisions and conventions need to be incorporate into the national laws of each consultative party. According to Article IX of the Treaty, to achieve the status of consultative party a country has to demonstrate

1 Departamento de Botânica, Campus Universitário Darcy Ribeiro, Universidade de Brasília, 70910-900, Brasília, DF, Brazil

2 Programa Antártico Brasileiro, PROANTAR, Brazil

* Corresponding author: paducamara@gmail.com 
its interest and commitment by developing a program of scientific research in the continent. Science in Antarctica, therefore, plays an unusually important role in regional geopolitics (Câmara \& Melo 2018; Mattos \& Câmara 2020).

\section{Brazil in Antarctica}

The presence of Brazil in Antarctica is not new, since the country acceded to the Antarctic Treaty in 1975 and achieved consultative status in 1983, after creating a scientific program specifically designed to supporting Antarctic science: The Brazilian Antarctic Program (PROANTAR). PROANTAR, ultimately, guarantees the status of Brazil among the countries that provide the governance for the entire continent, which inevitably includes decisions affecting the current and future protection and use of its resources, not least its freshwater reserves and potential mineral resources. Antarctica is also attracting increasing interest in more applied biotechnological fields, with very promising leads in bioprospecting, attempting to discover new products such as drugs, cosmetics, enzymes and biochemicals.

Brazil has no historical territorial claim in Antarctica and its national position is that the continent should be protected as heritage for future generations, fully dedicated to peace and science. Nevertheless, as expressed in the Brazilian National Defense Strategy (Brasil 2016), Antarctica forms part of the nation's strategic surroundings. As a consequence, the Brazilian parliament has passed a bill recognizing the country's ambition to expand its influence in the region, which can only be achieved through its scientific presence in Antarctica.

Following its accession to the Antarctic Treaty in 1975 and the creation of PROANTAR in 1983, in 1984 Brazil built its first (and only, to date) Antarctic station, "Comandante Ferraz" located in King George Island (Fig.1). However, in February 2012, it was almost completely destroyed due to a catastrophic fire, with the loss of two lives. Almost immediately after this tragic incident, plans for a new station were initiated and, in January 2020, a completely new station was inaugurated (Fig. 2). Its buildings comprise an area of 4,500 $\mathrm{m}^{2}$ and the station can accommodate up to 64 people, including 16 naval personnel responsible for running the station and 48 scientific staff.

The new station contains a building fully dedicated to science, "Ala Rocha Campos" in honor of Professor Antonio Carlos Rocha Campos (1937-2019) from the Universidade de São Paulo. This building contains 14 fully equipped laboratories, including laboratories dedicated to molecular biology, microbiology, chemistry, multiple use and microscopy, with two smaller rooms for general purpose use and one dedicated to studies on potential human pathogens. The building also contains climate-regulated wet laboratories equipped with marine and freshwater tanks, appropriate for studies on organisms such as algae, aquatic invertebrates

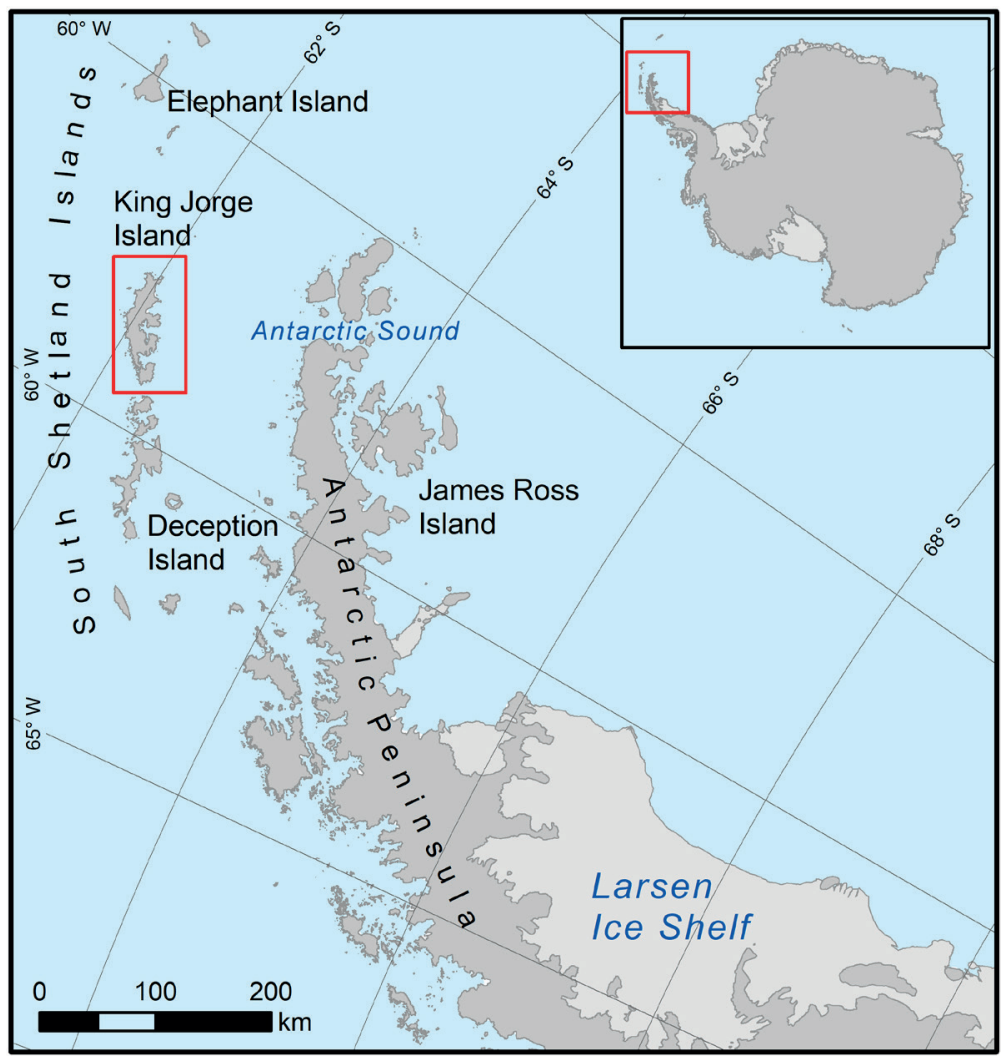

Figure 1. Antarctica Peninsula Region showing the location of King George Island, where the Brazilian Station is located. 
or fish. Separate to the building there are three external modules that also serve as laboratories, devoted respectively to meteorology, upper atmospheric studies and studies of sediments.

In addition to the newly replaced station, Brazil operates the Latin American Southernmost science module, Cryosphere 1 , located at about $84^{\circ} \mathrm{S}$ and ca. 2,000 km from Comandante Ferraz Station. This module is fully automated and sends real-time data, via satellite, to laboratories in Brazil. The Brazilian Navy operates two ice-strengthened polar research vessels dedicated to Antarctic Science. The Almirante Maximiano (Fig. 3) includes five laboratories and associated equipment, and mostly supports marine sciences. The Ary Rongel primarily supports logistic operations, but also includes one laboratory. Both ships operate with two helicopters, and also provide support to terrestrial field camping during austral summer campaigns (Fig. 4).

Between 1984 and 1991 Brazilian science in Antarctica was funded and directly supported by the Brazilian Navy. Since 1991, the Conselho Nacional de Desenvolvimento Científico e Tecnológico (CNPq) has taken responsibility for funding science in Antarctica, while the Navy kept providing the logistic support. The facilities described above are available for scientists to perform research projects approved by CNPq, with specific calls for grants to support work within PROANTAR usually being advertised every three-four years. International collaboration, as a founding principle of the Treaty, is strongly encouraged in PROANTAR as it is also strongly supported and facilitated by the Scientific Committee for Antarctic Research (SCAR).

\section{Botany in Antarctica}

There is a very common misconception that Antarctica, in most people's eyes, is a remote, frozen and barren place, with nothing of interest for a botanist or terrestrial biologist. However, nothing could be further from reality and botany is probably one of the first scientific disciplines that have been conducted in Antarctica. The first documented sighting of the South Shetland Islands was by William Smith in February 1819, and of the Antarctic Peninsula by Edward Bransfield in January 1820 . These were very rapidly followed by industrial sealers and whalers, who rapidly ravaged the populations of these marine mammals. Early, but vague, reports of Antarctic vegetation were recorded in sealers' and whalers' logbooks, and James Eights (1798-1882), naturalist to the U.S. Exploring Expedition (1829-1831), collected the first ever plant specimen in Antarctica, the moss Polytrichastrum alpinum (Hedw.) G.L. Sm. (Bryophyta, Polytrichaceae). This is one of the most common Antarctic mosses even today, and the original voucher specimens are still preserved in the New York Botanical Garden Herbarium (NY).

One of the first scientists to set foot in Antarctica was the famous botanist, Sir J.D. Hooker (1817-1911) on board James Clark Ross's expedition of 1839-1843. He was also the first specialist botanist to collect plants south of $60^{\circ}$ $\mathrm{S}$. His collections, including two species new to science, which were later published as the Flora Antarctica (Wilson \& Hooker 1847). For many years afterwards he remained as the only professional botanist to collect plants in Antarctica.

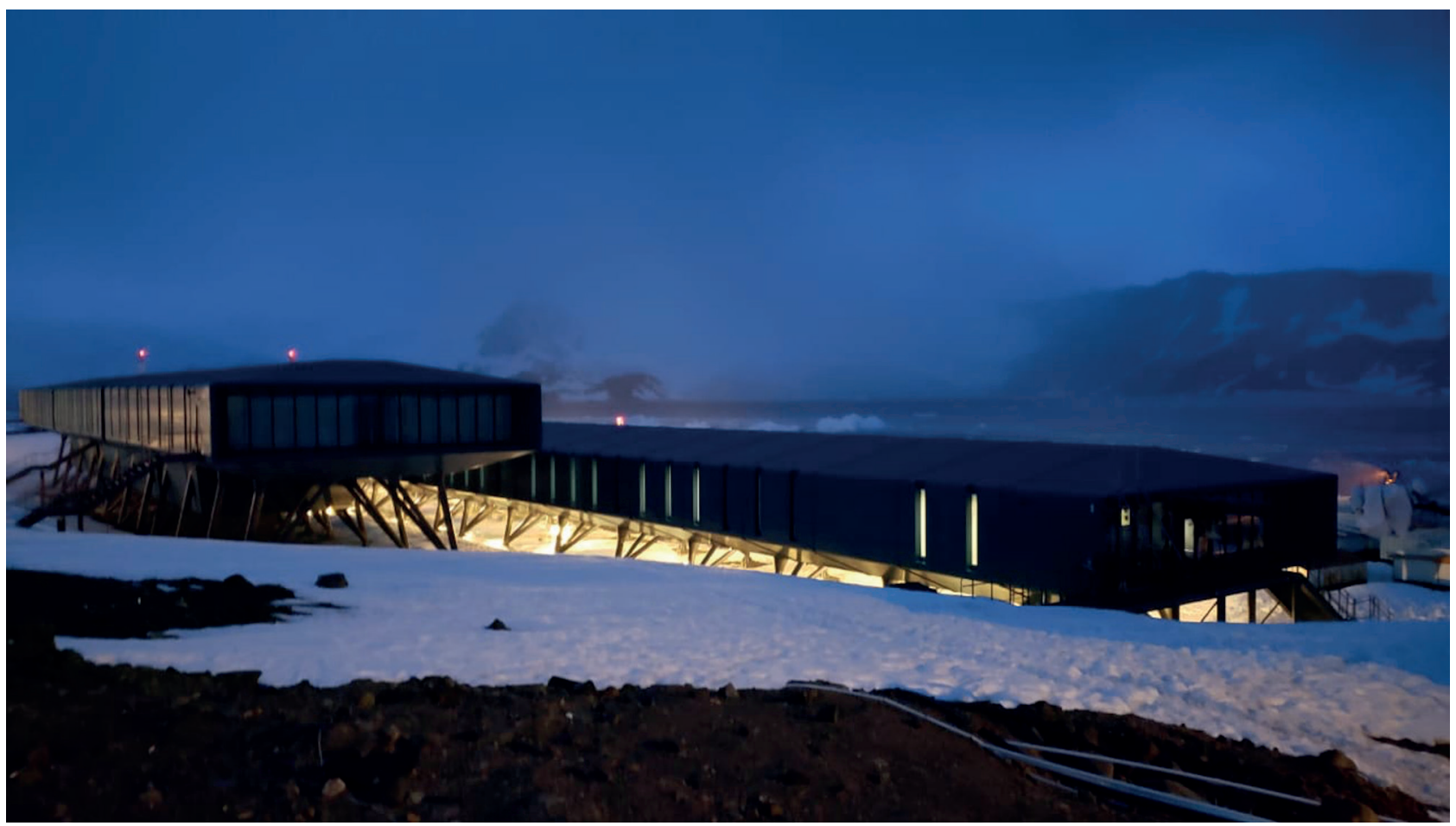

Figure 2. The new Comandante Ferraz Station. The building on the right contains the laboratories. The station is located on the Keller Peninsula, King George Island, South Shetland Islands. 


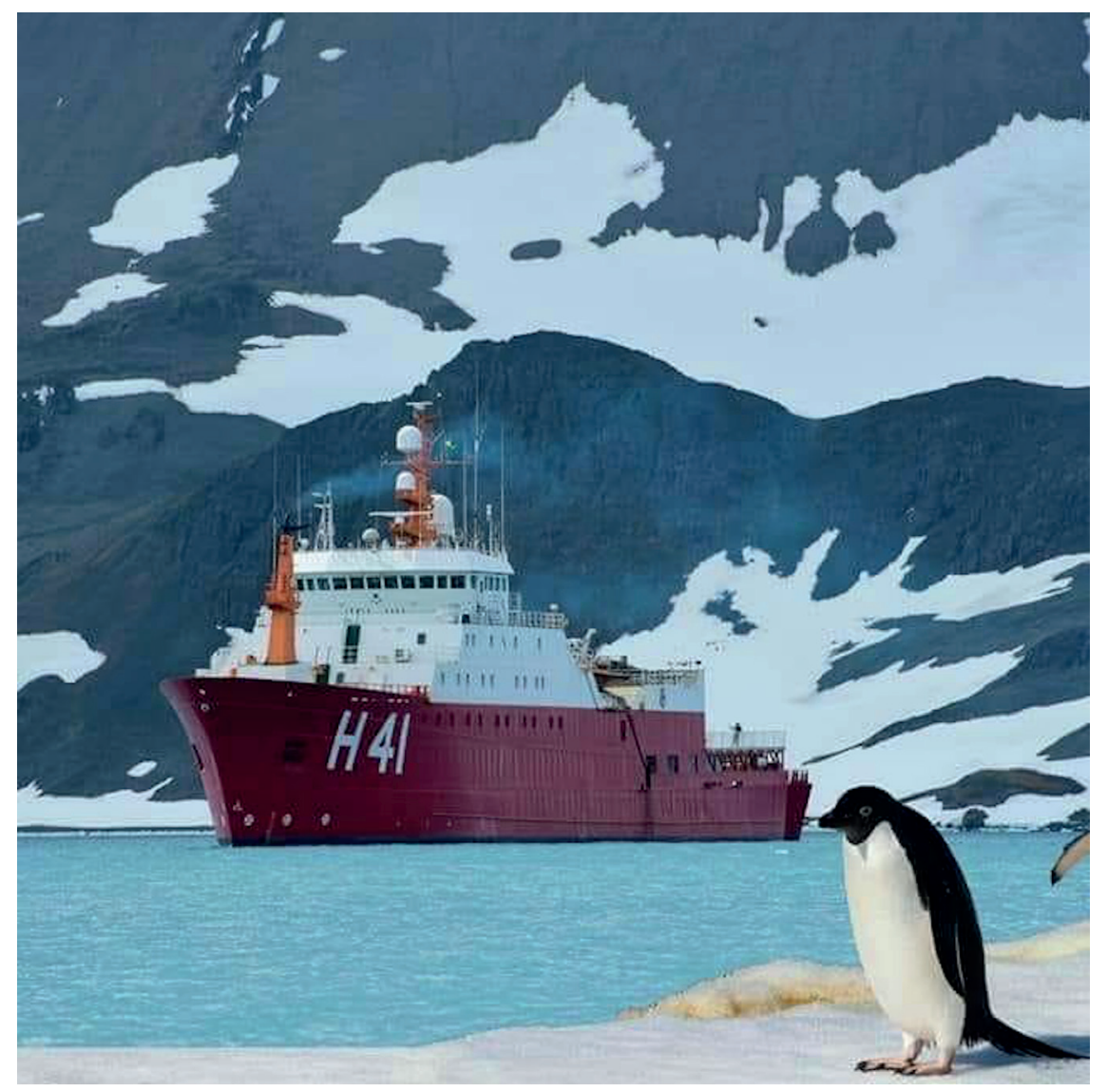

Figure 3. Brazilian Polar Vessel Almiramte Maximiano, a key platform for Brazilian Antarctic science, and fundamental for reaching study locations remote from Ferraz Station.

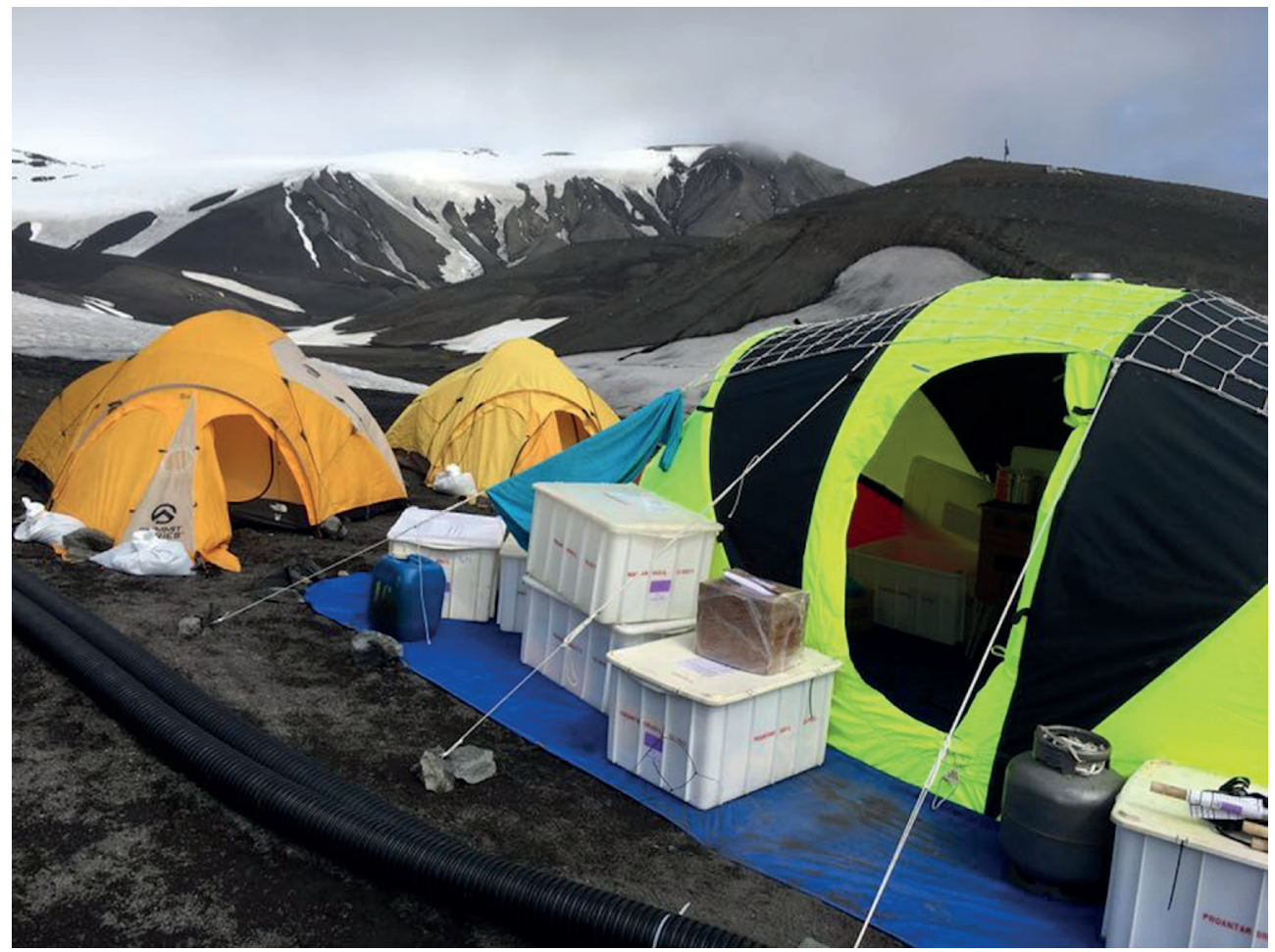

Figure 4. Brazilian field camp on Deception Island, South Shetland Islands. Such camps are often required to enable longer collecting expeditions remote from Ferraz Station. 
After the International Geographical Congress in the early 1890s suggested Antarctica to be the last frontier to be conquered by man, many expeditions set sail to the south. Many of these made collections of plants even though they did not include professional botanists, rather, these collections were made by physicians or scientists from other disciplines, such as the Romanian zoologist Emil Racovitza (1868-1947) on board the Belgica expedition (1897-1899) (for a comprehensive list of expeditions see Headland 1989). Many of the collections made during this period were later studied by the French botanist Jules Cardot (1860-1934) and the results published in La flore bryologique des terres magellaniques, de la Georgie du Sud et de l'Antarctide (Cardot 1908). Subsequently, expeditions continued to gather more collections and exploration of the continent became increasingly science oriented. Further impetus was given by the IGY (1957/8) and especially after the Antarctic Treaty came into force (1961).

However, even in the Antarctic Treaty era, relatively few specialist botanists have directly worked in the region, or extensively on Antarctic material. Among more recent botanists, (including Lichenologists) that have worked over long periods on Antarctic vegetation are Mackenzie Lamb (1911-1990), Stanley Greene (1928-1989), David Walton (1945-2019), Royce Longton (1939-), Ron Lewis Smith (1942-), Dag Øvstedal (1944-), Rod Seppelt (1945-), Richard Ochyra (1949-), Leopoldo Sancho (1956-), Peter Convey (1961-) and Paulo Câmara (1970-), not including algologists, plant physiologists, and other areas. The recent pinnacle of botanical investigation in Antarctica is represented by two key monographs, the Illustrated Moss Flora of Antarctica (Ochyra et al. 2008) and the Lichens of Antarctica and South Georgia (Øvstedal \& Smith 2001).

\section{Antarctic vegetation}

Antarctica's fossil record clearly shows how the continent's vegetation has changed over time, as the continent evolved from being an integral element of the supercontinent Gondwana to becoming the isolated and frigid continent that we know today (Convey et al. 2018b). That fossil record shows that, tens to hundreds of millions of years ago, Antarctica hosted lush and extensive temperate and even sub-tropical forests. In complete contrast, today's Antarctica, and even the relatively milder core sub-Antarctic islands, are located beyond the global tree line, and therefore lack trees and shrubs. As a result, the continent is a paradise for crypogamists - specialists in the 'lower' plant groups (mosses, liverworts, algae) and lichens. In terms of plant diversity, the Antarctic continent hosts just two native angiosperms, both limited to the Antarctic Peninsula and Scotia Arc archipelagoes - the grass Deschampsia antarctica E. Desv. (Poaceae) and the pearlwort Colobanthus quitensis (Kunth.) Bartl. (Caryophyllaceae), and also the invasive species
Poa annua L. (Poaceae) that was accidentally introduced by humans. Currently, around 116 species of Bryophyta (Ochyra et al. 2008; Ellis et al. 2013a; b; Sollman et al. 2015; Câmara et al. 2019) and 26 species of Marchantiophyta (Bednarek-Ochyra et al. 2000) are recognized from that region, along with about 500 species of lichens (Øvstedal \& Smith 2001). As in many fields of diversity research, these numbers are likely to increase with the application of modern molecular phylogenetic techniques leading to the recognition of potentially considerable cryptic diversity.

There was a long-held general belief that most if not all Antarctic vegetation (and more generally most terrestrial diversity) was driven from the continent as ice extent increased during the last glacial maximum and previous glacial cycles. This would mean that most species now present are relative 'newcomers', recolonizing their Antarctic distributions after subsequent ice retreat. However, as it is also the case for multiple Antarctic terrestrial invertebrate groups (Convey et al. 2008; 2018a), the use of molecular tools has suggested that some mosses (e.g. Bryum argenteum Hedw.) at least may have survived multiple glacial cycles in situ in refuges within Antarctica. The contemporary Antarctic flora therefore appears to be a mix of relictual survivors and recent colonists (Pisa et al. 2014; Biersma et al. 2017; 2018a; 2018b).

The limited ice-free areas of Antarctica provide a very low diversity of substrata, and plants grow on rocks, soil, epiphytically, bones, around freshwater bodies (including fully aquatic), and in unusual habitats provided by areas of geothermal activity such as volcanic fumaroles (Fig.5). Overall, plant diversity decreases as latitude increases, although this broad generalization does not describe well the patterns observed in the two main regions where true latitudinal gradients across available habitat exist (the Antarctic Peninsula and Scotia Arc, and the Victoria Land coastline leading into the Transantarctic Mountains (Peat et al. 2007; Convey et al. 2014). The former region, more generally known as Maritime Antarctica, contains the most diverse and abundant vegetation, especially in parts of the South Shetland and South Orkney Islands, with the continental Antarctic hosting much lower botanical diversity particularly of bryophytes (Ochyra et al. 2008).

As yet there is no form of 'red list' assessment of the vulnerability status of any Antarctic vegetation or other terrestrial biota. Even so, some Antarctica Especially Protected Areas (ASPAs) have been proposed and adopted specifically to protect their bryophyte and other vegetation diversity (e.g ASPA 140, Parts of Deception Island, South Shetland Islands). However, according to Hughes et al. (2016) the ASPA system has currently being assessed as providing inadequate protection to Antarctic terrestrial ecosystems in general (Shaw et al. 2014; Chown et al. 2015) and specifically to its vegetation, with more than half of all protected plant diversity across Antarctica being is included a single area (Byers Peninsula's ASPA). Furthermore, recent application of molecular biological approaches (Câmara et 
al. 2019) suggests that some species may be much rarer than previously thought.

\section{Main herbaria}

Most historical collections of Antarctic plants are nowadays housed at Belgium (BR), United Kingdon (BM), France (PC) and United States (NY) herbaria. More recent collections are housed in a small number of herbaria; the herbarium AAS houses the largest and most comprehensive collection of Antarctic vegetation, as well as from sub- and peri-Antarctic islands including the Falkland Islands, Kerguelen, Crozet, South Georgia, the South Sandwich Islands and others, with over 50,000 specimens. The Polish KRAM holds over 250,000 specimens of bryophytes, but is not restricted to Antarctica as it includes many collections from Central Europe. Hobart (HO) holds 18,000 specimens from Antarctica (at the incorporated Australian ADT herbarium). In Latin America the main collections are housed in Brazil (UB), with about 7,000 specimens from Antarctica, these also being some of the most recent ones to date.

A perhaps surprising range of botanical research continues in Antarctica or relying on Antarctic material today, particularly in the fields of ecology, climate change and plant physiology, biochemistry and 'omics'. However, it is not customary in such research, even when collections are made, for specimens to be formally deposited in herbaria, and thus most studied material remains inaccessible to other researchers. Reflecting a more general and increasingly challenge recognized elsewhere, very few plant taxonomists are currently active in Antarctic research. This has inevitably been compounded by the formal retirement of all the previous generation of Antarctic botanical expertise in recent years - including Seppelt, Longton, Ochyra, Lewis Smith - even though some have remained academically active since retirement, leading to an almost complete loss of trained plant taxonomists dedicated to Antarctic research.

\section{Brazilian Botany in Antarctica}

In the early years after PROANTAR's inception in 1984, little Brazilian Antarctic research was focused on botany. Botanical research in this period was carried out by mycologists such as Dr. Jair Putzke and Dr. Antonio Batista Pereira (UNIPAMPA), and was largely focused on phytosociology and ecology. Taxonomist Dr. Denise Pinheiro da Costa (JBRJ) was the first Brazilian plant taxonomist to supervise a master's dissertation on Antarctic botany (year 2005); she also made botanical collections in the South Shetland Islands in the 2014-15 summer season.

In 2013 PROANTAR funded, for the first time, a fully dedicated systematic, phylogenetic and taxonomic project on Antarctic botany. After the publication of Ochyra et al. (2008) Antarctic bryophyte monograph, there was a general belief in Brazil that little has remained to be investigated concerning the Antarctic vegetation. However, the application of modern DNA tools in Brazil's national research community has revealed many novelties, including a new genus (Câmara et al. 2017), new occurrences and new relationships among species (Câmara et al. 2018a; Suárez

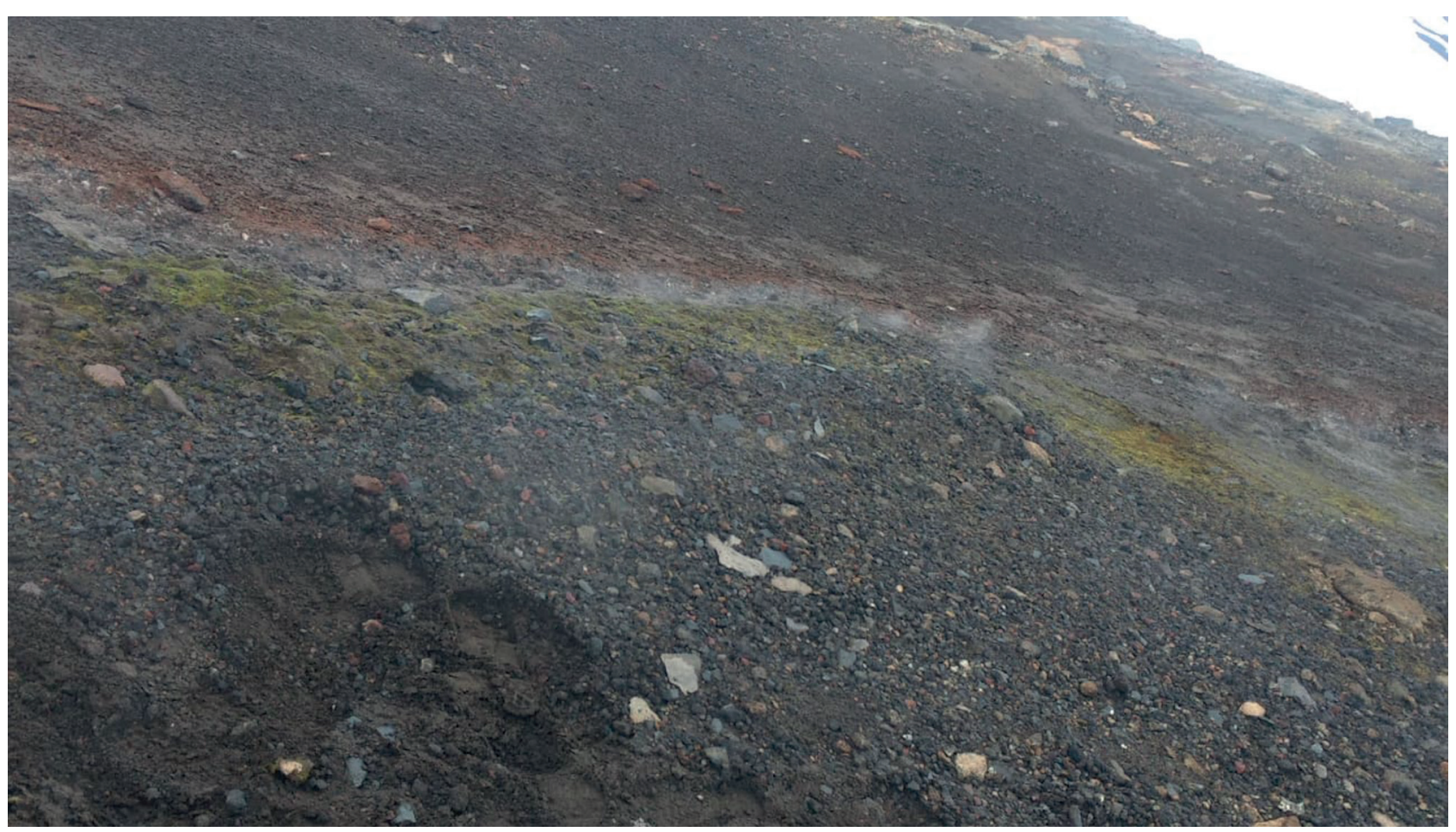

Figure 5. Moss growing on a fumarole on Deception Island, South Shetland Islands. 
et al. 2019), and also the effects of harsh environmental conditions on morphology (Câmara et al. 2018b).

Antarctica is characterized by its very harsh environmental conditions, which affects the way plants develop and their morphology. Without the use of molecular tools, reliance on morphology alone can be misleading. As molecular tools finally start to be increasingly applied in studies on Antarctic vegetation it is rapidly becoming clear that many new findings will be generated.

Under the auspices of this first dedicated project, three master's and one doctoral theses were completed, while many undergraduates were exposed to and enthused into becoming involved in polar science. Furthermore, outreach programs have brought polar science into schools, exposing both primary and secondary age schoolchildren and their teachers to the major challenges and concerns raised by Antarctic research and associated with the future of our planet.

\section{Final considerations}

Contrary to common thinking, Antarctica still hosts a large and surprising unexplored plant diversity, even when considering over 180 years since the first professional botanist set foot on the continent. Today, Brazil is one of very few countries to have a dedicated botanical program in Antarctica and the only one focused on taxonomy. The future use of molecular tools will be fundamental in increasing understanding of the true evolutionary relationships among species from Antarctica and their relatives at lower latitudes.

The Brazilian Antarctic science community now has cutting edge new facilities in the form of a new and fully-equipped scientific research station, as well as access to two polar research vessels and the possibility for support of deep-field remote expeditions. Together these facilities constitute a unique moment and opportunity for Brazilian botanists to make key contributions and play a central role in the development of the next generation of international Antarctic science.

\section{Acknowledgements}

We express our immense gratitude to all botanists that work or have worked in Antarctica, especially those that opened the frontiers for us and are no longer with us. We also thank Peter Convey from BAS, PROANTAR, Brazilian Navy, MCTIC and CNPq.

\section{References}

Bednarek-Ochyra H, Vana J, Ochyra R, Smith RIL. 2000. The Liverwort Flora of Antarctica. Krakow, Polish Academy of Sciences.

Biersma EM, Jackson JA, Hyvönen J, Linse K, Griffiths H, Convey P. 2017. Global biogeographic patterns in bipolar moss species. Royal Society Open Science 4: 170147. doi: 10.1098/rsos.170147

Biersma EM, Jackson JA, Stech M, Griffiths H, Linse K, Convey P. 2018a. Molecular data suggest long-term in situ Antarctic persistence within
Antarctica's most speciose plant genus, Schistidium. Frontiers in Ecology and Evolution 6: 77. doi: 10.3389/fevo.2018.00077

Biersma EM, Jackson JA, Bracegirdle TJ, Griffiths H, Linse K, Convey P. 2018b. Low genetic variation between South American and Antarctic populations of the bank-forming moss Chorisodontium aciphyllum (Dicranaceae). Polar Biology 41: 599-610.

Brasil. 2016. Ministério da Defesa. Política Nacional de Defesa e Estratégia Nacional de Defesa. Brasília, 2016. Aguardando aprovação do Congresso Nacional. https://www.defesa.gov.br/arquivos/2017/mes03/pnd_end.pdf Câmara PEAS, Carvalho-Silva M, Henriques DK, et al. 2018a. Pylaisiaceae Schimp. (Bryophyta) revisited. Journal of Bryology 64: 251-264.

Câmara PEAS, Melo RB. 2018. Brasil na antártica, os próximos 30 anos. Revista da Escola Superior de Guerra 33: 64-81.

Câmara PEAS, Silva BGC, Carvalho-Silva M, Henriques DK. 2017. The moss flora of Ostrov Geologov (Geologists Island), Maxwell Bay, King George Island, Antarctica. Boletín de la Sociedad Argentina de Botánica 52: 251-255.

Câmara PEAS, Soares AER, Hernriques DK, et al. 2019. New insights into the species diversity of Bartramia Hedw. (Bryophyta) in Antarctica from a morpho-molecular approach. Antarctic Science 31: 208-215.

Câmara PEAS, Valente DV, Amorim ET, et al. 2018b. Integrated analysis of intraspecific diversity in the bipolar moss Roaldia revoluta (Mitt.) P.E.A.S. Câmara \& M. Carvalho-Silva (Bryophyta) in Antarctica. Polar Biology 42: 485-496.

Cardot J. 1908. La flore bryologique des terres magellaniques, de la Georgie du Sud et de l'Antarctide. vol. 4. Stockholm, Litographisches Institut des Generalstabs.

Chown SL, Clarke A, Fraser CI. 2015. The changing form of Antarctic biodiversity. Nature 522: 431-438.

Convey P, Bowman VC, Chown SL, Francis JE, Fraser C, Smellie JL, Storey B, Terauds A. 2018b. Ice-Bound Antarctica: Biotic Consequences of the Shift from a Temperate to a Polar Climate. Mountains, Climate and Biodiversity. Oxford, John Wiley \& Sons.

Convey P, Chown SL, Clarke A. 2014. The spatial structure of Antarctic biodiversity. Ecological Monographs 84: 203-244.

Convey P, Coulson SJ, Worland MR, Sjöblom A. 2018a. The importance of understanding annual and shorter-term temperature patterns and variation in the surface levels of polar soils for terrestrial biota. Polar Biology 41: 1587-1605.

Convey P, Gibson J, Hillenbrand CD. 2008. Antarctic terrestrial life - Challenging the history of the frozen continent? Biological Reviews 83: 103-117.

Ellis LT, Asthana AK, Gupta R, et al. 2013a. New national and regional bryophyte records, 34. Journal of Bryology 35: 62-70.

Ellis LT, Bednarek-Ochyra H, Ochyra R, et al. 2013b. New national and regional bryophyte records, 35. Journal of Bryology 35: 129-139.

Headland RK. 1989. Chronological List of Antarctic Expeditions and Related Historical Events. Cambridge, Cambridge University Press.

Hughes KA, Ireland LC, Convey P, Fleming AH. 2016. Assessing the effectiveness of specially protected areas for conservation of Antarctica's botanical diversity. Conservation Biology 30: 113- 120.

Mattos LF, Câmara PEAS 2020. A ciência antártica como ferramenta geopolítica para o Brasil. Revista Marítima Brasileira 140: 15-23.

Ochyra R, Smith RIL, Bednarek-Ochyra H. 2008. The Illustrated Moss Flora of Antarctica. Cambridge, Cambridge University Press.

Øvstedal D O, Lewis Smith RI. 2001. Lichens of Antarctica and South Georgia. A guide to their identification and ecology. Cambridge, Cambridge University Press.

Peat HJ, Clarke A, Convey P. 2007. Diversity and biogeography of the Antarctic flora. Journal of Biogeography 34: 132-146.

Pisa S, Biersma EM, Convey P, Patiño J, Vanderpoorten A, Werner O. 2014. The cosmopolitan moss Bryum argenteum in Antarctica: recent colonization or in situ survival? Polar Biology 37: 1469-1477.

Shaw JD, Terauds A, Riddle MJ, Possingham HP, Chown SL. 2014. Antarctica's protected areas are inadequate, unrepresentative, at risk. PLoS Biology 12: e1001888 doi: 10.1371/journal.pbio.1001888

Sollman P. 2015. The genus Bryoerythrophyllum (Musci, Pottiaceae) in Antarctica. Polish Botanical Journal 50:19-25.

Suárez GM, Bordin J, Câmara PEAS. 2019. Syzygiella teres (Marchantiophyta) in the Elephant Island, Antarctica. Boletín de la Sociedad Argentina de Botánica 54: 185-189.

Wilson D, Hooker JD. 1847. Musci. In: Hooker JD. (ed.) The Botany of the Antarctic Voyage of H.M. Discovery Ships Erebus and Terror in the years 1839-1843, under the Command of Captain Sir James Clark Ross, Kt. R.N., F.R.S. London, Reeve Brothers. p. 395-551. 